\title{
A LOW-COST METHOD TO TEST CYTOTOXIC EFFECTS OF Crotalus vegrandis (SERPENTES:VIPERIDAE) VENOM ON KIDNEY CELL CULTURES
}

\author{
María E. GIRÓN(1), Irma AGUILAR(1), Lisandro ROMERO(2), Elda E. SÁNCHEZ(1,3), John C. PÉREZ(3) \& Alexis RODRIGUEZ-ACOSTA(1)
}

\begin{abstract}
SUMMARY
The pathogenesis of the renal lesion upon envenomation by snakebite has been related to myolysis, hemolysis, hypotension and/or direct venom nephrotoxicity caused by the venom. Both primary and continuous cell culture systems provide an in vitro alternative for quantitative evaluation of the toxicity of snake venoms. Crude Crotalus vegrandis venom was fractionated by molecular exclusion chromatography. The toxicity of $C$. vegrandis crude venom, hemorrhagic, and neurotoxic fractions were evaluated on mouse primary renal cells and a continuous cell line of Vero cells maintained in vitro. Cells were isolated from murine renal cortex and were grown in 96 well plates with Dulbecco's Modified Essential Medium (DMEM) and challenged with crude and venom fractions. The murine renal cortex cells exhibited epithelial morphology and the majority showed smooth muscle actin determined by immune-staining. The cytotoxicity was evaluated by the tetrazolium colorimetric method. Cell viability was less for crude venom, followed by the hemorrhagic and neurotoxic fractions with a $\mathrm{CT}_{50}$ of $4.93,18.41$ and $50.22 \mu \mathrm{g} / \mathrm{mL}$, respectively. The Vero cell cultures seemed to be more sensitive with a $\mathrm{CT}_{50}$ of 2.9 and $1.4 \mu \mathrm{g} / \mathrm{mL}$ for crude venom and the hemorrhagic peak, respectively. The results of this study show the potential of using cell culture system to evaluate venom toxicity.
\end{abstract}

KEYWORDS: Cellular cultures; Crotalus vegrandis; Kidney cells; Nephrotoxicity; Viperidae.

\section{INTRODUCTION}

In tropical countries ophidic accidents represent an important cause of morbidity and mortality. The World Health Organization ${ }^{7}$ has estimated 125,000 deaths annually throughout the world, 4,000 in South America and 1,000 in Central America caused by snakebites.

In Venezuela, $24 \%$ of these accidents correspond to those bitten by rattlesnakes of the genus Crotalus. Nevertheless, it is important to emphasize that many of these accidents occurring in rural communities are treated by physicians with inadequate training ${ }^{18}$.

Many of the Crotalus venom have myotoxic activity that leads to the development of rhabdomyolysis ${ }^{2}$. The myotoxic activity can be followed by skeletal muscle damage and the release of creatinophosphokinases (CPK), lactic dehydrogenase (LDH) and myoglobin. Hemorrhage is another common problem in many species of venomous snakes $^{1,14,19,21}$. All the above activities could cause renal lesions. In the present study, the activities of crude, hemorrhagic and neurotoxic fractions of $C$. vegrandis venom were evaluated on renal cells maintained in vitro and compared to Vero cells. This venom is of particular interest, since it is extremely hemorrhagic which is an uncommon condition of South American rattlesnake venom ${ }^{19}$.

\section{MATERIALS AND METHODS}

Animals: A NIH strain of male Albino Swiss mice between 18 - 22 $\mathrm{g}$ was maintained under laboratory conditions as outlined in the Guide of Principles of Laboratory Animal Care ${ }^{3}$. Mice were obtained from the National Institute of Hygiene "Rafael Rangel", Caracas, Venezuela.

Venom: A pool of crude venom from seven specimens of Crotalus vegrandis from the serpentarium of the Tropical Medicine Institute of the Universidad Central de Venezuela was used. The venom was centrifuged at $2000 \mathrm{x}$ g to remove non-soluble debris, lyophilized and frozen at $-85^{\circ} \mathrm{C}$ until used.

Lethality assay: Biostatistical method ${ }^{22}$ was used to calculate the lethal dose fifty $\left(\mathrm{LD}_{50}\right)$ of the $C$. vegrandis crude venom and venom fractions. The mice (18-22 g) were injected with $0.1 \mathrm{~mL}$ of various concentrations of venom and venom fractions and the number of mice that died were counted after $48 \mathrm{~h}$. The number of mice used at each dose level was four.

Protein determination: The total protein content was determined according to LOWRY et al. (1951) method $^{13}$.

(1) Immunochemistry Section, Tropical Medicine Institute of the Universidad Central de Venezuela, Caracas, Venezuela.

(2) Tissue Culture and Tumour Biology Laboratory of the Experimental Biology Institute of the Universidad Central de Venezuela, Caracas, Venezuela.

(3) Natural Toxins Research Center, Texas A\&M University-Kingsville, Texas, USA.

Correspondence to: Alexis Rodriguez-Acosta MD PhD, Apartado 47423, Caracas 1041, Venezuela. Fax: 582 6053550. E-mail: rodriguf@ucv.ve 


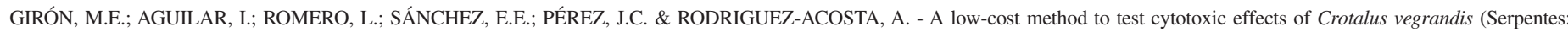
Viperidae) venom on kidney cell cultures. Rev. Inst. Med. trop. S. Paulo, 47(3): 147-152, 2005.

Venom fractionation: Crude venom $(3 \mathrm{mg}$ ) was dissolved in 0.5 $\mathrm{mL}$ of $0.2 \mathrm{M}$ ammonium acetate buffer, $\mathrm{pH} 6.9$ and loaded onto a Waters Protein Pak SW300 (10 - 300 kDa) molecular exclusion column (BioRad, Biologic Work Station). The venom was eluted with the same buffer. Fractions of $0.3 \mathrm{~mL}$ per tube at a flow rate of $0.5 \mathrm{~mL} / \mathrm{min}$ were collected. Elution of protein was monitored at $280 \mathrm{~nm}$ (Fig. 1).

Hemorrhagic and neurotoxic determination of fractions: All fractions were tested for hemorrhagic ${ }^{10}$ and neurotoxic activities ${ }^{20}$. For hemorrhagic peak (P1) $100 \mu \mathrm{L}$ containing 5-50 $\mu \mathrm{g}$ were injected intradermal into the abdominal skin of four male NIH Swiss albino mice. The mice were sacrificed after two h, and the inner skin surface was observed for hemorrhage. Neurotoxic peak (P3) activities were clinically evaluated by examination of breathing difficulty, flaccid paralysis, exophthalmia, bradycardia and finally death ${ }^{20}$.

Statistical analysis: Statistical comparisons using median and standard deviation were made. Three self-directed experiments were performed for each venom sample.

Renal cells culture: Primary cells were obtained from mouse renal cortex. Cells were enzymatic treated with trypsin $25 \mathrm{mM}-0.04 \%$ EDTA (Gibco, USA) for $20 \mathrm{~min}$. The cellular suspension was centrifuged in DMEM (Sigma, USA) at $30 \mathrm{x}$ g for three min to discard debris in the supernatant. The pellet was resuspended and centrifuged again at 150 $\mathrm{x} \mathrm{g}$ for three min. The resulting pellet was diluted in DMEM containing $10 \%$ fetal bovine serum (FBS), and cultured in $75 \mathrm{~cm}^{2}$ flasks (FALCON Plastics, Los Angeles, CA).
The flasks were previously coated with $1 \%$ gelatine employed as a substrate ${ }^{6}$, and maintained at $37{ }^{\circ} \mathrm{C}$ in a humid atmosphere, $5 \% \mathrm{CO}_{2}$ for 8-10 days until the monolayer reached a confluence of more than $80 \%$. After this, the supernatant was removed and cells detached with trypsin-EDTA in DMEM.

The cellular suspension was centrifuged and the pellet was resuspended in DMEM, the cells were counted and seeded into 96 well plates. Cellular morphology was evaluated by using a MayGründwald-Giemsa stain.

An immunoassay ${ }^{9}$ was used to identify mesangial, fibroblast and epithelial cells under a light microscopy. Monoclonal antibodies specific against smooth muscle actin, vimentin, and cytokeratin (conjugated with avidin-biotin-peroxidase) (DAKO Corp., Carpintería, CA) were used to identify mesangial, fibroblast and epithelial cells, respectively.

Vero-murine cellular line: Monolayers of Vero cells (Ethiopian kidney green monkey cells from American type cell collection CCL81) in the logarithmic phase of growth were harvested with a mixture trypsin-EDTA in DMEM. The cellular suspension was centrifuged at $150 \mathrm{x} \mathrm{g}$ and the pellet resuspended in 10\% FBS-DMEM. Then, cells were cultured in DMEM and used for the cytotoxic assay.

Cytotoxicity assay: A method ${ }^{16}$ was used to evaluate cytotoxicity on kidney and Vero cells. The cells were cultured in 96 wells microtiter plates at a concentration of $6 \times 10^{3}$ cells/well, and incubated at $37^{\circ} \mathrm{C}$, in a $5 \% \mathrm{CO}_{2}$ incubator. After $48 \mathrm{~h}$ the culture supernatant was changed

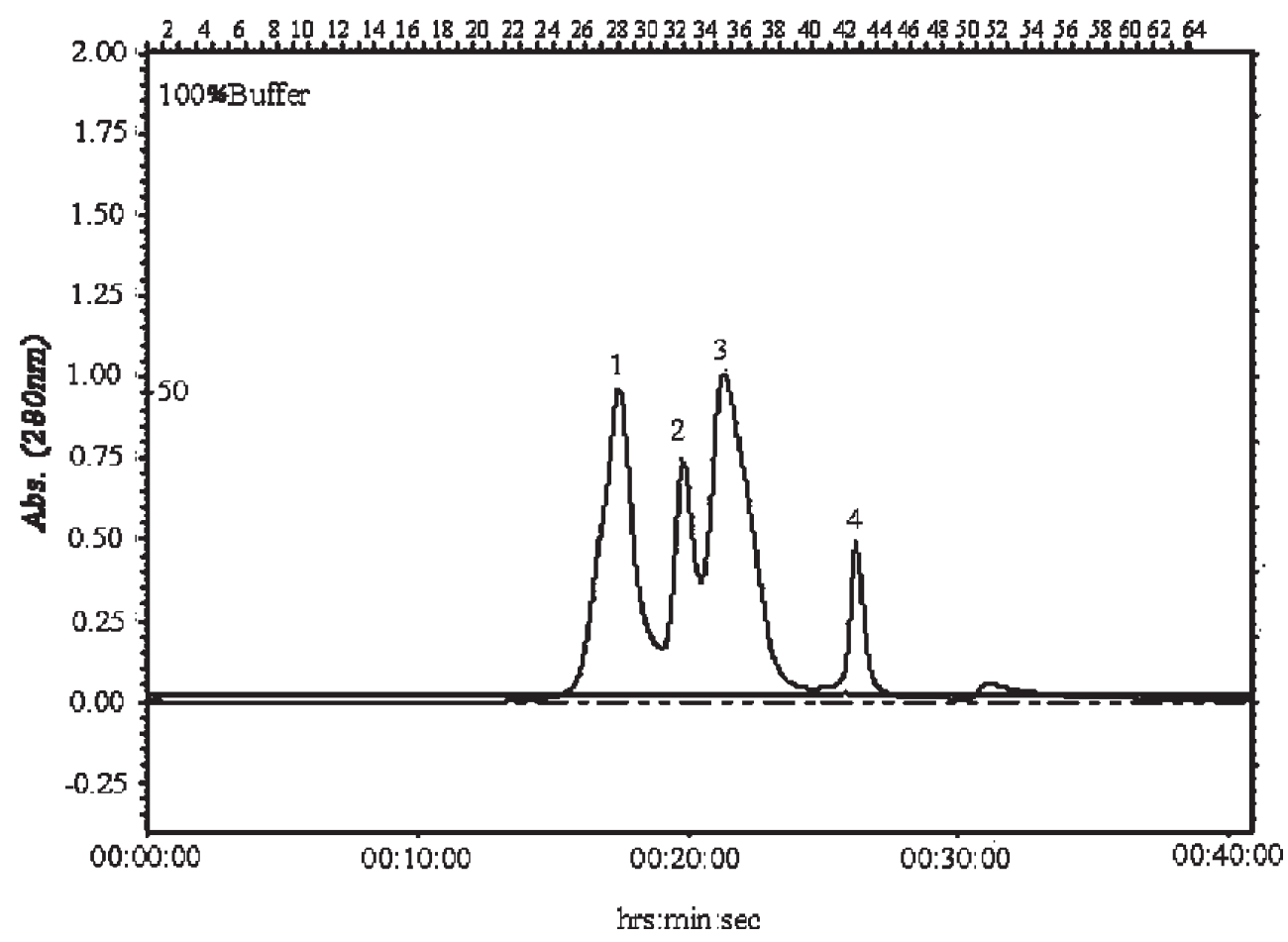

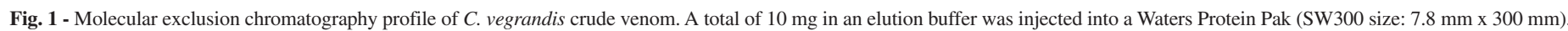
$0.2 \mathrm{M}$ ammonium acetate buffer, $\mathrm{pH} 6.9$ at a flow rate of $0.5 \mathrm{~mL} / \mathrm{min}$. 
and different amounts $(0.1,1.0,5.0,10$ and $20 \mu \mathrm{g} / \mathrm{mL})$ of crude venom or peaks (final volume of medium containing the different amounts of venom) were added. The plates were incubated for $18 \mathrm{~h}$. Then, the medium was removed by aspiration and without washing, $100 \mu \mathrm{L}$ of MTT (methyl-tetrazolium [3-(4,5-dimethylthiazol-2-yl)-2,5diphenyltetrazolium bromide]) (Sigma, USA) at a concentration of $0.4 \mathrm{mg} / \mathrm{mL}$ was added to each well. The plates were incubated for four $\mathrm{h}$ at $37^{\circ} \mathrm{C}$ in a $5 \% \mathrm{CO}_{2}$ incubator. After staining, fiber-like mesh was observed at the bottom of each well, the medium was discarded and $100 \%$ dimethyl sulfoxide (DMSO) was gently added, followed by incubation at room temperature for $30 \mathrm{~min}$. The absorbance of plates was measured in an ELISA reader (Microplate reader series 7500, Cambridge Technology, USA) at a wavelength of $570 \mathrm{~nm}$.

Three independent experiments were accomplished using renal primary cell lines and Vero cells with each crude venom and purified fracions.

Cytotoxicity $\left(\mathrm{CT}_{50}\right)$ was measured by a curve interpolation at $570 \mathrm{~nm}$, after plotting the mean percentage of surviving cells against the concentration in $\mu \mathrm{g} / \mathrm{mL}$ of crude venom and peaks, where $50 \%$ of the cellular population survived, with respect to the controls of $100 \%$ of the cellular culture in absence of any sample (Figs. 2 and 3) (Tables 1 and 2).

\section{RESULTS}

Venom fractionation: C. vegrandis venom was fractionated into four peaks by size exclusion chromatography (Fig. 1). Peak 1 (P1) exhibited hemorrhagic activity and peak 3 (P3) neurotoxic activity without hemorrhagic action.

Determination of lethality: The $\mathrm{LD}_{50}$ for crude venom was 0.27 $\mathrm{mg} / \mathrm{kg}$ body weight. No $\mathrm{LD}_{50}$ was determined for P1 at concentrations between 2 - $200 \mu \mathrm{g}$. The $\mathrm{LD}_{50}$ for P3 was $0.135 \mathrm{mg} / \mathrm{kg}$ body weight.

Hemorrhagic activity: Mice injected with P1 were sacrificed after two h showing an intense hemorrhage in the inner skin surface. This peak, clinically tested did not show any neurotoxic activity.

Neurotoxic activity: To test neurotoxic activity ${ }^{20}$ an intramuscular venom injection in mice, at $0.135 \mathrm{mg} / \mathrm{kg}$ body weight, produced muscular weakness and hypotonia, followed by a flaccid paralysis, breathing difficulty, exophthalmia, bradycardia and death. The neurotoxic activity only was found in the peak 3 , which did not show hemorrhagic activity.

Cellular cultures: Under a light microscope the cultures presented homogeneous appearance and confluence. The cells exhibited classical polygonal shape epithelial cell morphology with May-GrünwaldGiemsa staining. Ninety percent of the cellular population resulted positive for anti-smooth muscle actin, 5\% were positive cells for cytokeratin and all were negative for vimentin immune-labeling (data not shown) before treating with venom and venom peaks.

Cytotoxicity assay: The cytotoxicity profiles are shown in the Figs. 2 and 3 and $\mathrm{CT}_{50}$ in Tables 1 and 2 . In kidney cell cultures, the viability was less for crude venom compared with hemorrhagic and neurotoxic peaks $\left(\mathrm{CT}_{50}: 4.9,18.4\right.$ and $50.2 \mu \mathrm{g} / \mathrm{mL}$, respectively). In Vero cell cultures, the $\mathrm{CT}_{50}$ was 2.9 and $1.4 \mu \mathrm{g} / \mathrm{mL}$ for crude venom and the hemorrhagic peak, respectively. The $\mathrm{CT}_{50}$ was not determined for the neurotoxic peak in Vero cells because even at high venom concentrations $(2-200 \mu \mathrm{g} / \mathrm{mL})$ it was not lethal. The Vero cells were more sensitive than kidney cells to hemorrhagic peak.

\section{Kidney cells}

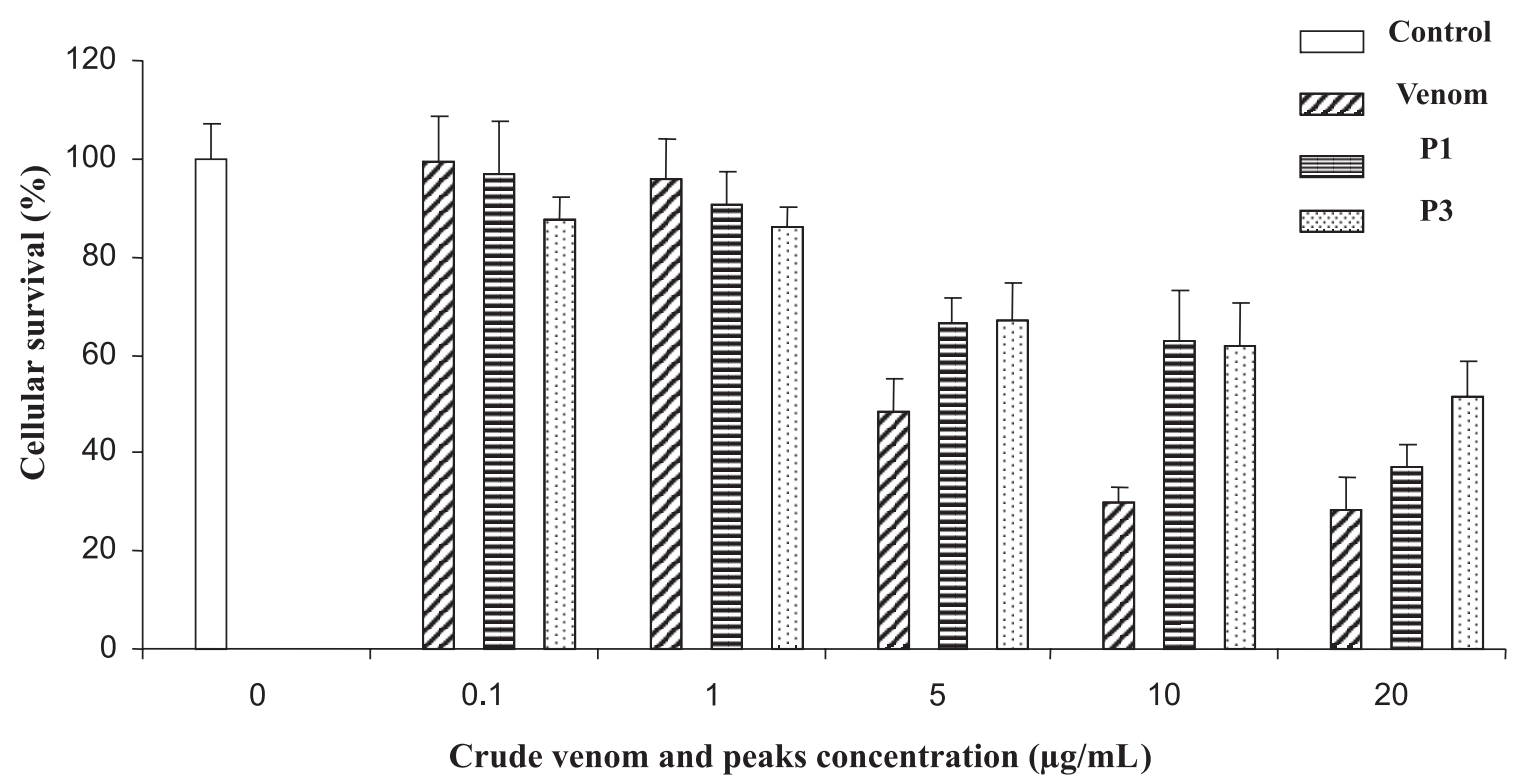

Fig. 2 - Percentage and standard deviation ( $\mathrm{T}$ ) of cellular culture survival of Crotalus vegrandis crude venom, hemorrhagic (P1), neurotoxic (P3) peaks and control on kidney cells. 


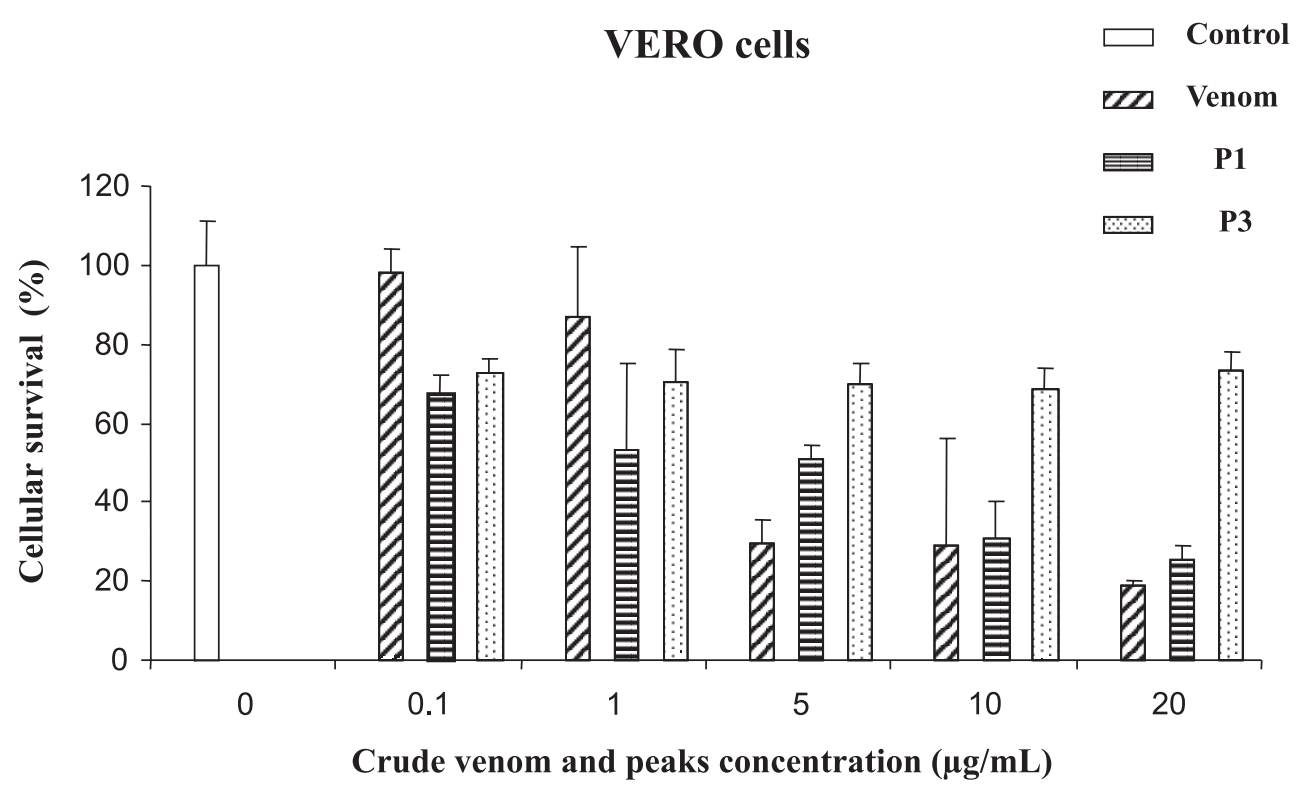

Fig. 3 - Percentage and standard deviation $(T$ ) of cellular culture survival of Crotalus vegrandis crude venom, hemorrhagic (P1), neurotoxic (P3) peaks and control on Vero cells.

Table 1

Cytotoxicity fifty $\left(\mathrm{CT}_{50}\right)$ from Crotalus vegrandis crude venom, hemorrhagic (P1) and neurotoxic (P3) peaks on cultured kidney cells

\begin{tabular}{cc}
\hline $\mathrm{CT}_{50}$ & $(\mu \mathrm{g} / \mathrm{mL})$ \\
\hline Crude venom & 4.926 \\
$\mathrm{P} 1$ & 18.408 \\
$\mathrm{P} 3$ & 50.223 \\
\hline
\end{tabular}

$\mathrm{CT}_{50}$ was calculated by the formula: $\mathrm{Y}=\mathrm{aLnX}+\mathrm{b}$ (EXCEL WINDOWS 2000)

Table 2

Cytotoxicity fifty $\left(\mathrm{CT}_{50}\right)$ from Crotalus vegrandis crude venom, hemorrhagic (P1) and neurotoxic (P3) peaks on cultured Vero cells

\begin{tabular}{cc}
\hline $\mathrm{CT}_{50}$ & $(\mu \mathrm{g} / \mathrm{mL})$ \\
\hline Crude venom & 2.889 \\
$\mathrm{P} 1$ & 1.407 \\
$\mathrm{P} 3$ & Non-calculable \\
\hline
\end{tabular}

$\mathrm{CT}_{50}$ was calculated by the formula: $\mathrm{Y}=\mathrm{aLnX}+\mathrm{b}$ (EXCEL WINDOWS 2000)

\section{DISCUSSION}

Culture systems have been useful in understanding the toxicity of many different compounds. In particular, the kidney is a vulnerable organ to help remove toxins, due to its high blood flow and its capacity to concentrate substances in the urine. The use of a primary cell line has permitted us to evaluate the toxicity of venom, in a relatively short period of time with little expense. In these events, the development of these primary cultures to evaluate the direct toxicity is important, since other studies have reported the toxicity of venom to other types of cell lines ${ }^{11,12,15,17}$. GIRÓN et al. ${ }^{8}$ demonstrated that the intravenous and intraperitoneal administration of $C$. vegrandis crude venom or its fractions induced damage that encompasses the area of proximal tubules, interstice, peritubular vessels, and damage to the glomerular capillary endothelial cells as target of its action, in absence of hemoglobin or myopigment.

The development of cellular culture systems for the study of toxic drugs, chemical, and biological substances has increased. Cell culture systems can prevent the over use of animal models to study toxins. The cellular culture assay will probably never completely replace the animal model, but will permit comparisons of the direct toxicity of a compound and their neutralization. It also allows the study of toxicity mechanisms and the discrimination if a toxin is nephrotoxic ${ }^{6}$.

In the present study, under light microscopy the cultures presented homogeneous appearance and confluence in eight to 10 days. The cells exhibited epithelial morphology and an immunoassay suggested that the population was mostly mesangial type cells.

STRIKER \& STRIKER ${ }^{23}$ established that according to the conditions and the time of culture, the growth of a given cellular type could be favored. The epithelial cell types during the first days under low concentrations of serum prevailed; while after eight to 10 days of culture, and with serum concentrations of $10-20 \%$, the mesangial type cells were seen favored, as observed in our experiments.

Chemical and biological activities on in vitro cell cultures have been standardized by counting viable cells with various "dye exclusion tests". In this study, the loss of cellular viability is based on the plasma membrane integrity and it is a time consuming method ${ }^{16}$.

LOMONTE et al. ${ }^{11}$, evaluated the metalloprotease activity of Bothrops asper venom on endothelial cells maintained in vitro, quantifying the cytotoxicity by the release of LDH into the culture media. LOMONTE et al. ${ }^{12}$, working with skeletal muscle and murine 


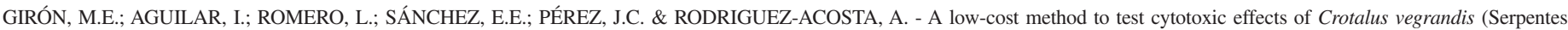
Viperidae) venom on kidney cell cultures. Rev. Inst. Med. trop. S. Paulo, 47(3): 147-152, 2005.

endothelial cellular lines evaluated the cellular damage provoked by snake venom phospholipases by also quantifying LDH release.

OLIVEIRA et al. ${ }^{17}$ employed a quantitative method of cellular survival by using supravital neutral red staining after exposing the cells to Bothrops venoms. In that study, the quantity of neutral red incorporated by the cells was directly proportional to the number of viable cells in the culture.

Another method that has been employed to evaluate the venom toxicity on cells, quantifying the optical density of the viable cells is the MTT method ${ }^{16}$. MTT is a soluble salt of tetrazolium, which is transformed into a purple soluble compound or formazan when the tetrazolium ring is broken by dehydrogenases enzymes liberated from active mitochondria.

In this study, the crude $C$. vegrandis venom as well as their hemorrhagic and neurotoxic peaks were capable of inducing changes in the primary renal and Vero cell cultures, as quantified by MTT method. These results suggested that the Vero cells were susceptible to the crude venom and purified fractions, particularly to the hemorrhagic peak, but less susceptible to the neurotoxic peak since it was not possible to estimate its $\mathrm{CT}_{50}$. The poorer cytolytic outcome of the neurotoxic peak (almost certainly crotoxin) in this in vitro example may be a sign of a low dissociation of both crotoxin subunits (A and B), or maybe due a comparatively low density of high affinity binding sites on the cell membrane, where Vero cells has probably less binding sites as primary cell line. In general, the viability was less for both cell cultures when crude venom was used. This can best be explained by the fact that crude venom contains many different toxins and that could act individually or synergistically ${ }^{4}$.

In the kidneys, the pathogenesis seems to be multifactorial. It has been related to myolysis, hemolysis, hypotenson, hypersensibility to venom components, and a direct toxic effect of the venom on tubular cells ${ }^{8}$.

The culture of renal cells in the presence of crude venom seems more comparable to the animal model than the Vero cell cultures, since the crude venom $\mathrm{CT}_{50}$ value $(4.9 \mu \mathrm{g} / \mathrm{mL})$ for renal cells was similar to the $\mathrm{LD}_{50}$ estimated for a $20 \mathrm{~g}$ mouse $(5.4 \mu \mathrm{g} / \mathrm{mL})$.

With the results obtained in this study, the usefulness of cellular cultures to evaluate venom toxicity in a quantitative form is proposed. The MTT assay is a rapid, simple and very economic method that allowed the evaluation and comparison of many samples, as well as to estimate the $\mathrm{CT}_{50}$ of crude venom and its peaks. This method is less expensive than other assays using commercial kits such as LDH measurement. Furthermore, the development of a renal cellular culture system for the quantitative evaluation of the toxic venom effects in absence of systemic interactions would provide an alternative method to the in vivo assay.

\section{RESUMEN}

\section{Un método de bajo costo para probar los efectos citotóxicos del veneno de Crotalus vegrandis (Serpentes: Viperidae) en cultivos de células renales}

La patogénesis de la lesion renal ha sido relacionada a la miolisis, hemólisis, hipotensión y/o el efecto directo del veneno. Tanto el cultivo primario o el cultivo celular continuo proveen una alternativa in vitro para la evaluación cuantitativa de la toxicidad de venenos de serpiente. El veneno crudo de Crotalus vegrandis fue fraccionado por una cromatografía de exclusión molecular. La toxicidad del veneno crudo de $C$. vegrandis, sus fracciones hemorrágicas y neurotóxicas fueron evaluadas en células renales primarias de ratón y una línea continua de células Vero mantenidas in vitro. Las células fueron aisladas de la corteza renal murina y se cultivaron en placas de 96 pozos con medio Dulbecco (DMEM). Allí fueron tratadas con el veneno crudo y sus fracciones. Las células de la corteza renal murina tuvieron una morfología de células epiteliales y la mayoría se tiñeron con un anticuerpo anti-músculo actina. La citotoxicidad fue evaluada por el método colorimétrico del tetrazolium. La viabilidad de las células fue menor en las células tratadas con el veneno crudo, seguida por la fracción hemorrágica y neurotóxica, con un $\mathrm{CT}_{50}$ de $4.93,18.41$ y $50.22 \mu \mathrm{g} / \mathrm{mL}$, respectivamente. Los cultivos de células Vero parecieron ser más sensibles con un $\mathrm{CT}_{50}$ de 2.9 y $1.4 \mu \mathrm{g} /$ $\mathrm{mL}$ para el veneno crudo y el pico hemorrágico, respectivamente. Los resultados de este estudio muestran la potencialidad de usar sistemas de cultivo celular para evaluar la toxicidad de los venenos.

\section{REFERENCES}

1. AgUilar, I.; GIRÓN, M.E. \& RODRIGUEZ-ACOSTA, A. - Purification and characterisation of a haemorrhagic fraction from the venom of the Uracoan rattlesnake Crotalus vegrandis. Biochim. Biophys Acta, 1548: 57-65, 2001.

2. AMARAL, C.F.S.; REZENDE, N.A.; DA SILVA, O.A. et al. - Insuficiência renal aguda secundária a acidentes ofídicos, botrópico e crotálico. Análise de 63 casos. Rev. Inst. Med. trop. S. Paulo, 28: 220-227, 1986

3. ANONYMOUS - Principles of laboratory animal care. Maryland, National Institute of Health of United States, 1985. p. 1-86.

4. BJARNASON, J.B. \& FOX, J.W. - Hemorrhagic toxins from snake venoms. J. Toxicol. Toxin Rev., 7: 121-209, 1988-1989.

5. BURDMANN, E.A.; WORONIK, V.; PRADO, E.B. et al. - Snakebite-induced acute renal failure: an experimetal model. Amer. J. trop. Med. Hyg, 48: 82-88, 1993.

6. CHERIAN, M.G. - Rat kidney epithelial cell culture for metal toxicity studies. In vitro cell. develop. Biol., 21: 505-508, 1985.

7. CHIPPAUX, J.P. - Snake-bites: appraisal of the global situation. Bull. Wld. HIth. Org., 76: 515-524, 1998.

8. GIRÓN, M.E.; PINTO, A.; FINOL, H.J.; AGUILAR, I. \& RODRÍGUEZ-ACOSTA, A. Kidney structural and ultrastructural pathological changes induced by Uracoan rattlesnake (Crotalus vegrandis Klauber 1941) venom. J. submicrosc. Cytol. Path., 34: 447-459, 2002.

9. HSU, S.M.; RAINE, L. \& FANGER, H.J. - Use of Avidin-Biotin-peroxidase Complex $(\mathrm{ABC})$ in immunoperoxidase techniques: a comparison between $\mathrm{ABC}$ and unlabeled antibody (PAP) procedures. J. Histochem. Cytochem, 29: 557-580, 1981.

10. KONDO, H.; KONDO, S.; IKESAWA, H. \& MURATA, R. - Studies on the quantitative method for determination of hemorrhagic activity of Habu snake venom. Jap. J. med. Sci. Biol, 13: 43-52, 1960.

11. LOMONTE, B.; GUTIERREZ, J.M.; BORKOW, G. et al. - Activity of hemorrhagic metalloproteinase BaH-1 and myotoxin II from Bothrops asper snake venom on capillary endothelial cells in vitro. Toxicon, 32: 505-510, 1994.

12. LOMONTE, B.; ANGULO, Y.; RUFINO, S. et al. - Comparative study of the cytolytic activity of myotoxic phospholipases A2 on mouse endothelial (tEnd) and skeletal muscle (C2C12) cells in vitro. Toxicon, 37: 145-158, 1999. 
GIRÓN, M.E.; AGUILAR, I.; ROMERO, L.; SÁNCHEZ, E.E.; PÉREZ, J.C. \& RODRIGUEZ-ACOSTA, A. - A low-cost method to test cytotoxic effects of Crotalus vegrandis (Serpentes: Viperidae) venom on kidney cell cultures. Rev. Inst. Med. trop. S. Paulo, 47(3): 147-152, 2005.

13. LOWRY, O.H.; ROSEBROUGH, N.J.; FARR, A.L. \& RANDALL, R.J. - Protein measurement with the folin phenol reagent. J. biol. Chem., 193: 265-275, 1951.

14. MARKLAND, F.S. - Snake venom and the hemostatic system. Toxicon, 36: 1749-1800, 1998.

15. MARTIKAINEN, P.; NYMAN, K. \& NEVALAINEN, T.J. - Toxic effects of human pancreatic and snake and bee venom phospholipases A2 on MCF-7 cells in culture. Toxicon, 31: 835-843, 1993.

16. MOSMANN, T. - Rapid colorimetric assay for cellular growth and survival: application to proliferation and cytotoxicity assays. J. immunol. Meth., 65: 55-63, 1983.

17. OLIVEIRA, J.C.R.; MONTES DE OCA, H.; DUARTE, M.M.; DINIZ, C.R. \& FORTESDIAS, C.L. - Toxicity of South American snake venoms measured by an in vitro cell culture assay. Toxicon, 40: 321-325, 2002.

18. RODRÍGUEZ-ACOSTA, A.; MONDOLFI, A.; ORIHUELA, R. et al. - ¿Qué hacer frente a un accidente ofídico? Caracas, Venediciones C.A., 1995. p. 1-108.

19. RODRÍGUEZ-ACOSTA, A.; AGUILAR, I.; GIRÓN, M.E. \& RODRÍGUEZ-PULIDO, V. - Haemorrhagic activity of Neotropical Rattlesnake (Crotalus vegrandis Klauber, 1941). Natur. Toxins, 6: 15-18, 1998.
20. SCANNONE, H.R.; GRILLO-RODRIGUEZ, O. \& LANCINI, A.R. - Enzymatic activities and other characteristics of Crotalus vegrandis snake venom. In: ROSEMBERG, C., ed. Animal, plant and microbial toxins. New York, Pergamon Press, 1978 p. 223-229.

21. SOTO, J.G.; PÉREZ, J.C. \& MINTON, S.A. - Proteolytic, hemorrhagic, and hemolytic activities of snake venoms. Toxicon, 26: 875-882, 1988.

22. SPEARMAN-KARBER R. - Alternative methods of analysis for quantal responses. In FINNEY, D. Statistical method in biological assay. London, Charles Griffin, 1978. p. $1-78$.

23. STRIKER, G.E. \& STRIKER, L.J. - Glomerular cell culture. Lab. Invest., 53: 122-131, 1985.

Received: 12 August 2004

Accepted: 4 March 2005 